\title{
Evapotranspiration of a declining Quercus robur (L.) stand from 1999 to 2001. I. Trees and forest floor daily transpiration
}

\author{
Caroline VINCKE ${ }^{\mathrm{a} *}$, Nathalie BREDA ${ }^{\mathrm{b}}$, André GRANIER $^{\mathrm{b}}$, Freddy DEVILLEZ $^{\mathrm{a}}$ \\ ${ }^{a}$ Unité des Eaux et Forêts, Faculté d'ingénierie biologique, agronomique et environnementale, Université Catholique de Louvain, \\ Croix du Sud, 2/9, 1348 Louvain-la-Neuve, Belgium \\ ${ }^{\mathrm{b}}$ Équipe bioclimatologie-Écophysiologie. INRA-Centre de recherches de Nancy, 54280 Champenoux, France
}

(Received 15 November 2004; accepted 2 March 2005)

\begin{abstract}
Water use of a Quercus robur (L.) declining stand was estimated from 1999 to 2001 by measuring independently tree canopy and herb layer transpiration. Two plots differing in density were compared. Oak daily sap flux density kinetic is well synchronised with potential evapotranspiration (PET) daily time course. Despite differences in density, stand structure and LAI spatial organisation, oak transpiration $\left(T, \mathrm{~mm} \mathrm{~d}^{-1}\right)$ is quite the same between plots. The declining trees are very responsive to the PET fluctuations, but their daily response is low $\left(T \leq 1 \mathrm{~mm} \mathrm{~d}^{-1} ; T / P E T<0.3\right)$. A combination of soil constraints and low, disorganised LAI could induce this low transpiration capability. According to its phenology, density and the above canopy closure, the herbaceous layer contributes to at least the same but often more water consumption than the oak (up to $2.9 \mathrm{~mm} \mathrm{~d}^{-1}$ ). Therefore it cannot be neglected in water balance calculations.
\end{abstract}

sap flux / tree transpiration / herbaceous transpiration / LAI / oak decline

Résumé - Evapotranspiration d'un peuplement de chêne pédonculé (Quercus robur L.) dépérissant, de 1999 à 2001 . I. Transpiration journalière des arbres et de la strate herbacée. L'utilisation de l'eau par un peuplement de chênes dépérissant $(Q$. robur L.) a été estimée de 1999 à 2001 par des mesures indépendantes de transpiration des arbres et de transpiration de la strate herbacée. Deux parcelles de densité différente ont été comparées. Les cinétiques journalières de densité de flux de sève des chênes sont bien synchronisées avec celles de l'évapotranspiration potentielle $(E T P)$. Malgré des différences de densité et de structure des parcelles ainsi que d'organisation spatiale de l'indice foliaire $(L A I)$, la transpiration des chênes $\left(T, \mathrm{~mm} \mathrm{j}^{-1}\right)$ est sensiblement la même dans les deux parcelles. Les arbres dépérissants répondent aux fluctuations de l'ETP, mais leur transpiration journalière est faible $\left(T \leq 1 \mathrm{~mm} \mathrm{j}^{-1} ; T / E T P<0.3\right)$. La combinaison de contraintes hydriques et d'un $L A I$ faible et désorganisé pourrait induire cette faible capacité transpiratoire. Selon sa phénologie, sa densité et la fermeture de la canopée, la strate herbacée consomme souvent plus d'eau que les chênes (jusqu'à $2.9 \mathrm{~mm} \mathrm{j}^{-1}$ ). Elle ne peut dès lors pas être négligée dans le calcul du bilan hydrique de ces parcelles.

flux de sève / transpiration ligneuse / transpiration herbacée / indice foliaire / dépérissement du chêne

\section{INTRODUCTION}

Whole-tree estimates of water use have been the subject of numerous researches since the 1930's. Among the available techniques, heat dissipation and heat-pulse methods have been increasingly used $[41,42]$ because they give insight in tree physiology through sap flux radial pattern and velocity $[21,38]$. Forest water use can be estimated on a ground area basis from whole-tree water use measurements if appropriate scalars are used [50]. Yet, forest heterogeneity complicate this task especially in mixed and/or multi-layered stands. For instance, according to its development, the herbaceous cover contributes to stand water use from $6 \%$ to $65 \%$ [3, 20, 28, 37].

Water use of several broad-leafed species have already been studied, among which Quercus petraea [7], Quercus robur [10] and Fagus sylvatica $[11,18]$. But few studies treated the case of declining stands, pedunculate oak declining stands in par- ticular [5, 44]. Whereas Becker and Lévy [1, 2] demonstrated that $Q$. robur decline was mainly due to recurrent and intense droughts, still no tree water use measurements have been done on such trees. Among the decline symptoms, a disorganised branching pattern, a foliage reduction, the clustering of leaves are usually observed $[29,33]$. Tree physiology is altered as well as the overall forest structure through the impacts of a less dense canopy cover. Therefore one can reasonably assume that declining stands and/or trees present a water use regulation different from that of healthy ones.

The objectives of this paper are to estimate (i) water use of declining pedunculate oaks and (ii) forest floor water use, in two plots differing in density and canopy structure and during 3 successive years (1999-2001). On the basis of those results, a companion paper [48] estimates stand daily evapotranspiration from 1999 to 2001, and discuss the relative contribution of each layer in the stand water use.

\footnotetext{
* Corresponding author: vincke@efor.ucl.ac.be
} 


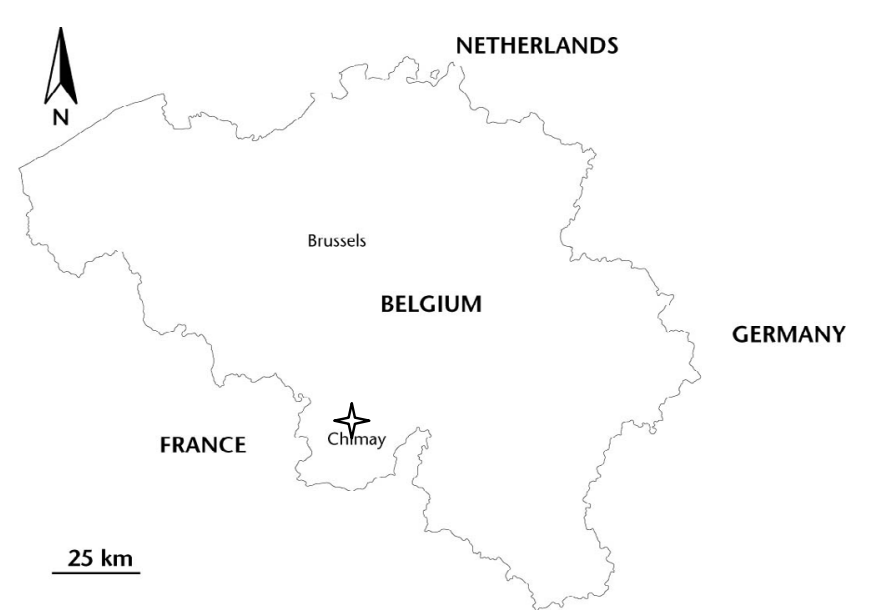

Figure 1. Geographical localization of the study site in Belgium.

\section{MATERIALS AND METHODS}

\subsection{Environmental settings}

The study area is located in the South of Belgium $\left(50^{\circ} 06^{\prime} \mathrm{N}, 4^{\circ}\right.$ 16 ' E; Fig. 1) at an elevation of $260 \mathrm{~m}$. Topography is flat. Climate is humid temperate with mean annual precipitation of $960 \mathrm{~mm}$ and mean temperature of $8.4{ }^{\circ} \mathrm{C}$. Mean annual potential evapotranspiration $(P E T)$ is $526 \mathrm{~mm}$, with $88 \%$ occurring between April and October (maximum in July and August).

Soils are dystric Cambisol [15]. The B structural horizon rests on a clayey substratum (up to $51.8 \%$ of clay) appearing at $30 \mathrm{~cm}$ depth; a temporary ground water table is present from late fall to late spring with an upper limit around $0.35-0.5 \mathrm{~m}$ deep. The water table floor corresponds to poorly weathered schist stratum, located at $1.7-2.1 \mathrm{~m}$ depth [39]. The water table drops rapidly below $0.70 \mathrm{~m}$ depth (in average, from mid-June until mid-September). Those soils present severe signs of hydromorphy. Though the soil horizons are dense at depth > $0.45 \mathrm{~m}$, roots were observed down to $1.6 \mathrm{~m}$ [47]. The soil water reserve was estimated to be $600 \mathrm{~mm}$ at field capacity by the use of soil moisture measurements (Thetaprobes, Delta-T, Cambridge, UK; data not shown).

The forest stand, $2.4 \mathrm{~km}^{2}$ in extent, was planted on an agricultural land in 1892 with Pinus sylvestris L. and Quercus robur L. The former was delivered as soon as it competed the oaks. During the 1940's, different broad-leaved species were introduced in the understorey (Prunus avium L., Fraxinus excelsior L., Quercus rubra L., Betula sp., Acer pseudoplatanus L., Alnus sp.). The forest floor vegetation is constituted mainly by Circaea lutetiana L., Stachys sylvatica L., Carex pendula Huds., Athyrium filix femina (L.) Roth and Rubus fruticosus L., the latest being the most covering. In the control plot, Prunus spinosa $\mathrm{L}$. shrubs are found in patches.

\subsection{Experimental design and environmental monitoring}

A thinned plot (Th.; $1682 \mathrm{~m}^{2}$ ) and a control one (C.; $1323 \mathrm{~m}^{2}$ ) were created in 1993. In each plot, oaks are arranged in five rows; two more rows separate the plots. Thinning (May 1993) removed 32\% of oak basal area. Most of the thinned trees were healthy or suffering from less than $25 \%$ of crown leaf loss according to visual assessment [43]. Decline symptoms appeared since the mid 1980's. In 1999, oak crowns were more than $25 \%$ defoliated in $60 \%$ and $40 \%$ of the thinned and the control plots trees, respectively.

The present study started 6 years after thinning, i.e., in 1999 and up to 2001. In the thinned plot (Tab. I), oak density remained constant during the 3 years $\left(107\right.$ trees $^{-1}$ ) and basal area increased from 13.8 to $14.2 \mathrm{~m}^{2} \mathrm{ha}^{-1}$. In the control plot, density and basal area decreased respectively from 189 to 159 trees $\mathrm{ha}^{-1}$ and from 20.9 to $18.3 \mathrm{~m}^{2} \mathrm{ha}^{-1}$. The average height of oak in both plot is $24 \mathrm{~m}$.

Besides pedunculate oak, forest overstory basal area is dominated by Acer pseudoplatanus L. (Th.: 10\%; C.: 11.3\%) and Fraxinus excelsior L. (Th.: 5.3\%; C.: 8\%) ; Prunus avium L. and Quercus rubra L. contribute respectively for $2.7 \%$ and $1.1 \%$ in the control plot and Quercus rubra L. contributed for $4.2 \%$ in the thinned plot. Total overstory basal area was $17.5 \mathrm{~m}^{2} \mathrm{ha}^{-1}$ in the thinned plot and $28 \mathrm{~m}^{2} \mathrm{ha}^{-1}$ in the control one (Tab. I). Quercus rubra and Fraxinus are part of the dominant canopy respectively in the thinned and the control plot; Acer is an intermediate species, reaching approximately $17 \mathrm{~m}$ in both plots [46].

LAI-2000 Plant Canopy Analyser (Li-Cor, Lincoln, NE, USA) and litterfall collection measurements were managed to estimate tree $L A I$ [46]. Total Leaf Area Index ( $L A I$, Tab. I) for the three years was respectively $3.6,3.1$ and 3.5 in the thinned plot ( $75 \%$ from pedunculate oak, $14 \%$ from $Q$. rubra and 5\% from Acer) and 4.3, 3.7 and 4.2 in the control plot (53\% from pedunculate oak, $25 \%$ from Acer and $11 \%$ from Fraxinus).

An automatic weather station (PAMESEB, Libramont, Belgium) monitored the local climate in an open area $1 \mathrm{~km}$ from the stand at an hourly time step: precipitation ( $1 \mathrm{~m}$ height), wind speed (anemometer "Thermistor", $1.8 \mathrm{~m}$ height), global radiation (photovoltaic sensor "solar Haeni 130", $1.5 \mathrm{~m}$ height), air temperature (resistance sensor "Thermistor", $1.5 \mathrm{~m}$ height) and relative humidity (psychrometer "Thermistor", $1.5 \mathrm{~m}$ height) were recorded. Potential evapotranspiration (PET) was calculated according to the Penman formula [36].

\subsection{Sap flux density (SFD) measurements and ligneous stand transpiration $(T)$}

Xylem sap flux density ( $S F D, 1 \mathrm{H}_{2} \mathrm{O} \mathrm{h}^{-1} \mathrm{dm}^{-2}$ sapwood) was monitored on 3 (1999) and 4 (2000-2001) pedunculate oaks and on 1 maple (2000-2001) in each plot (Tab. II). Sampled oaks were representative of the plot's mean basal area tree circumference (Th.: $125 \mathrm{~cm}$; C.: $115 \mathrm{~cm}$ ) and were suffering from less than $25 \%$ leaf loss. Radial sapflow sensors [16] were inserted $1.3 \mathrm{~m}$ above soil surface in the north side of stems, to avoid direct solar heating. Those sensors (UP GmbH,

Table I. Oak basal area $\left(G, \mathrm{~m}^{2} \mathrm{ha}^{-1}\right)$, oak mean circumference at breast-height $\left(C_{130}, \mathrm{~cm}\right)$, oak density $\left(N \mathrm{ha}^{-1}\right)$ and maximum $L A I$ in 1999 , 2000 and 2001; basal area $\left(G, \mathrm{~m}^{2} \mathrm{ha}^{-1}\right)$ and maximum $L A I$ when considering all tree species in each plot (All). Th.: Thinned; C.: Control.

\begin{tabular}{|c|c|c|c|c|c|c|c|c|c|c|c|c|c|c|c|c|}
\hline & \multicolumn{6}{|c|}{1999} & \multicolumn{5}{|c|}{2000} & \multicolumn{5}{|c|}{2001} \\
\hline & \multicolumn{4}{|c|}{ Oak } & \multicolumn{2}{|c|}{ All } & \multicolumn{4}{|c|}{ Oak } & All & \multicolumn{4}{|c|}{ Oak } & All \\
\hline & $G$ & $C_{130}$ & $N \mathrm{ha}^{-1}$ & $L A I$ & $G$ & $L A I$ & $G$ & $C_{130}$ & $N$ ha $^{-1}$ & LAI & $L A I$ & $G$ & $C_{130}$ & $N$ ha $^{-1}$ & LAI & $\overline{L A I}$ \\
\hline Th. & 13.8 & 126.4 & 107 & 2.8 & 17.4 & 3.6 & 14 & 127.2 & 107 & 1.9 & 3.1 & 14.2 & 128 & 107 & 2.5 & 3.5 \\
\hline C. & 20.9 & 116.2 & 189 & 2.8 & 28 & 4.3 & 19 & 118.1 & 166.3 & 2.3 & 3.7 & 18.3 & 118.8 & 158.7 & 2.5 & 4.2 \\
\hline
\end{tabular}


Table II. For 1999, 2000 and 2001, characteristics of the trees equipped with radial flowmeters, per plot (Th.: Thinned; C.: Control) and per species: tree number (No.), period during which measurements were performed (Years), circumference in $1999\left(C_{\mathrm{i}}, \mathrm{cm}\right)$, sapwood thickness $(\mathrm{cm})$ and sapwood area $\left(S A, \mathrm{~cm}^{2}\right)$, crown projected area $\left(S_{\mathrm{c}}, \mathrm{m}^{2}\right)$, total height $(H, \mathrm{~m})$, height of first epicormic shoots occurrence $\left(H_{\mathrm{e}}, \mathrm{m}\right)$, trunk height below crown $\left(H_{\mathrm{c}}, \mathrm{m}\right)$, visual UE crown assessment $(C E E)$ and annual circumference increment measured with dial-dendro $\left(I_{\mathrm{c}}, \mathrm{cm}\right)$.

\begin{tabular}{|c|c|c|c|c|c|c|c|c|c|c|c|c|c|c|c|c|}
\hline & \multirow[b]{2}{*}{ Species } & \multirow[b]{2}{*}{ No. } & \multirow[b]{2}{*}{ Years } & \multirow[b]{2}{*}{$C_{\mathrm{i}}$} & \multicolumn{2}{|c|}{ Sapwood } & \multirow[b]{2}{*}{$S_{\mathrm{c}}$} & \multicolumn{3}{|c|}{ Height } & \multicolumn{2}{|c|}{1999} & \multicolumn{2}{|c|}{2000} & \multicolumn{2}{|c|}{2001} \\
\hline & & & & & Thickness & $S A$ & & $H$ & $H_{\mathrm{e}}$ & $H_{\mathrm{c}}$ & $C E E$ & $I_{\mathrm{c}}$ & $C E E$ & $I_{\mathrm{c}}$ & $C E E$ & $I_{\mathrm{c}}$ \\
\hline \multirow{5}{*}{$\mathrm{Th}_{2}$} & \multirow{4}{*}{$\begin{array}{l}\text { Quercus } \\
\text { robur }\end{array}$} & 1 & 1999-2001 & 122.8 & 4.6 & 456.2 & 36.3 & 22.7 & 3.7 & 13.3 & 1 & 0.8 & 1 & 0.8 & 1 & 0.8 \\
\hline & & 2 & 1999-2001 & 130.5 & 2.55 & 288.2 & 46.1 & 25.2 & 9.6 & 12.6 & 2 & 0.5 & 2 & 0.75 & 2 & 0.45 \\
\hline & & 3 & 1999-2001 & 112.8 & 3.4 & 318.7 & 45.4 & 22.9 & 6 & 11.4 & 2 & 0.3 & 2 & 1 & 2 & 0.8 \\
\hline & & 4 & 1900-2001 & 131.2 & 2.45 & 279.3 & 58.7 & 22.9 & 3 & 10.9 & 1 & 0.85 & 1 & 0.9 & 1 & 1.2 \\
\hline & Acer & 5 & 1900-2001 & 77.7 & 5.83 & 345.6 & 57.5 & 17 & - & 2.2 & - & - & - & - & - & - \\
\hline \multirow{5}{*}{$\mathrm{C}_{2}$} & \multirow{4}{*}{$\begin{array}{l}\text { Quercus } \\
\text { robur }\end{array}$} & 1 & 1999-2001 & 114.4 & 1.95 & 198.9 & 29.2 & 24.4 & 5.6 & 13.8 & 1 & 0.9 & 1 & 1.1 & 1 & 0.6 \\
\hline & & 2 & 1999-2001 & 121.1 & 2.45 & 256.6 & 56.5 & 23.6 & 5.2 & 10.8 & 1 & 0.55 & 1 & 0.9 & 1 & 0.8 \\
\hline & & 3 & 1999-2001 & 129.9 & 2.9 & 232.2 & 57.8 & 25.9 & 12.3 & 14.3 & 1 & 0.4 & 1 & 0.4 & 2 & 0.45 \\
\hline & & 4 & 2000-2001 & 124.9 & 3 & 318.7 & 52 & 24.9 & 6.2 & 14.8 & 1 & - & 2 & - & 2 & - \\
\hline & Acer & 5 & 2000-2001 & 40.5 & 3.02 & 93.9 & 25.7 & 13.9 & - & 5.6 & - & - & - & - & - & - \\
\hline
\end{tabular}

Cottbus, Germany) consist in a pair of probes, $2 \mathrm{~cm}$ long and $0.2 \mathrm{~cm}$ in diameter each, inserted in a radial orientation behind the cambial zone. The probes were placed into freshly bored holes separated vertically by $15 \mathrm{~cm}$. The temperature difference between the heated and reference probes $(\Delta T)$ was recorded and by comparing it with the maximum occurring at predawn (Tmax), SFD was calculated according to Granier [16]. $\Delta T$ was recorded every minute from bud break to leaf fall and 30-min averages were stored using a DL3000 (Delta-T, Cambridge, UK). For each tree, sap flow $\left(S F, 1 \mathrm{~h}^{-1}\right)$ was obtained by multiplying $S F D$ by sapwood area $\left(S A, \mathrm{dm}^{2}\right)$. Oak $S A$ was measured on cores taken at $130 \mathrm{~cm}$ height at the end of the 1999 growing season. For maple, $S A\left(\mathrm{~cm}^{2}\right)$ was derived from an allometric relationship (Eq. (1)) with diameter at breast-height $(D B H, \mathrm{~cm})$, cited in Mathieu [31]:

$$
S A=0.565 \mathrm{DBH}^{2} \quad R^{2}=0.947
$$

Oak $S A$ reached $3.2 \mathrm{~m}^{2} \mathrm{ha}^{-1}\left(296 \mathrm{~cm}^{2}\right.$ per tree) in the thinned plot and $4.2 \mathrm{~m}^{2} \mathrm{ha}^{-1}\left(243 \mathrm{~cm}^{2}\right.$ per tree) in the control plot. For Acer, $S A$ was respectively $0.24 \mathrm{~m}^{2} \mathrm{ha}^{-1}$ and $1.45 \mathrm{~m}^{2} \mathrm{ha}^{-1}$. Sapflow sensors were replaced each year. Oak and maple daily stand transpiration $\left(T, \mathrm{~mm} \mathrm{~d}^{-1}\right)$ were calculated as follows [7]:

$$
T=\Sigma T j
$$

with

$$
T_{j}=S A_{\mathrm{j}} / G A \Sigma S F D_{\mathrm{i}} p_{\mathrm{i}}
$$

where $j$ stands for a species, $G A$ for the ground area $\left(\mathrm{m}^{2}\right), S F D_{\mathrm{i}}$ is the sap flux density of tree $\mathrm{i}\left(\mathrm{h} \mathrm{h}^{-1} \mathrm{dm}^{-2}\right)$ and $p_{\mathrm{i}}$ is the proportion of trees with sapwood area $S A_{\mathrm{i}}$ in the stand (Tab. III). Oak and maple $S F D$ are considered as representative of the ring-porous (Quercus rubra, Fraxinus excelsior) and diffuse-porous (Betula sp., Prunus sp., Crataegus sp., Carpinus betulus, Fagus sylvatica) species, respectively.

\subsection{Herbaceous transpiration and $L A I$}

Herbaceous transpiration was measured during 6 days in 2001 growing season ( 4 in the thinned plot and 2 in the control one) with a mobile closed chamber [13]. This device is a parallelepiped chamber of $0.76 \times 0.76 \times 1 \mathrm{~m}\left(0.563 \mathrm{~m}^{3}\right)$ composed of transparent plastic walls with removable base and top. The chamber is equipped with 4 PAR Quantum sensors (Skye instruments LTD, Powys, UK), one psychrometer H301/TR (Vector Instruments, Rhyl, UK), one air temperature probe SKTS 200 (Skye instruments LTD, Powys, UK) and 3 ven- tilators (to homogenise air humidity). One measurement location was chosen in each plot, representative of that plot herbaceous species composition and cover. At the beginning of a measurement, the chamber is set down on the location and kinetics of 2-3 min, with records of each instrument every $2 \mathrm{~s}$, are realised. Between measurements, the chamber was opened and displaced to be aerated. For each kinetics (20 to 30 per day) a transpiration rate per ground area is derived $\left(E_{\mathrm{k}}, \mathrm{mm} \mathrm{s}^{-1}\right)$. The integration of each $E_{\mathrm{k}}$ measurement gives the daily transpiration $\left(E_{\mathrm{d}}, \mathrm{mm} \mathrm{d}^{-1}\right)$. It should be noted that this device integrates soil evaporation as well: output is rather the herb layer evapotranspiration.

Forest floor $L A I$ was estimated by collecting all leaves in each plot on $1 \mathrm{~m}^{2}$ areas in May, June and November 2001 and in January 2002. The leaves were then surfaced with Scion Image Software (Scion corporation, Frederick, USA).

\section{RESULTS}

\subsection{Sap flux densities diurnal pattern}

Daily time courses of mean $S F D\left(\mathrm{~L} \mathrm{dm}^{-2} \mathrm{~h}^{-1}\right)$ per plot (Fig. 2) for DOY 162 of each year $\left(P E T \approx 2.7 \mathrm{~mm} \mathrm{~d}^{-1}\right.$ in all years) showed an asymmetrical bell-shaped curve, with a steep

Table III. For each plot (Th.: Thinned; C.: Control), frequency of pedunculate oak trees by sapwood area class $(S A)$ expressed in num-

\begin{tabular}{|c|c|c|c|c|c|c|c|c|c|}
\hline \multirow{3}{*}{$S A\left(\mathrm{~cm}^{2}\right)$} & \multirow{2}{*}{\multicolumn{3}{|c|}{$\begin{array}{c}\text { Th. } \\
\text { 1999-2001 }\end{array}$}} & \multicolumn{6}{|c|}{ C. } \\
\hline & & & & \multicolumn{3}{|c|}{1999} & \multicolumn{3}{|c|}{ 2000-2001 } \\
\hline & $N$ & $p i$ & No. & $N$ & $p i$ & No. & $N$ & $p i$ & No. \\
\hline 100 & 4 & 22.2 & - & 15 & 60 & 1 & 13 & 56.5 & 1 \\
\hline 200 & 5 & 27.8 & $2-(4)$ & 3 & 12 & 2 & 3 & 13 & 2 \\
\hline 300 & 5 & 27.8 & 3 & 4 & 16 & 3 & 4 & 17.4 & $3-4$ \\
\hline 400 & 4 & 22.2 & 1 & 3 & 12 & & 3 & 13 & - \\
\hline
\end{tabular}
bers of trees $(N)$ and percentages (pi, \%); No. is the number of the tree equipped with radial flowmeters (cf. Tab. II). 


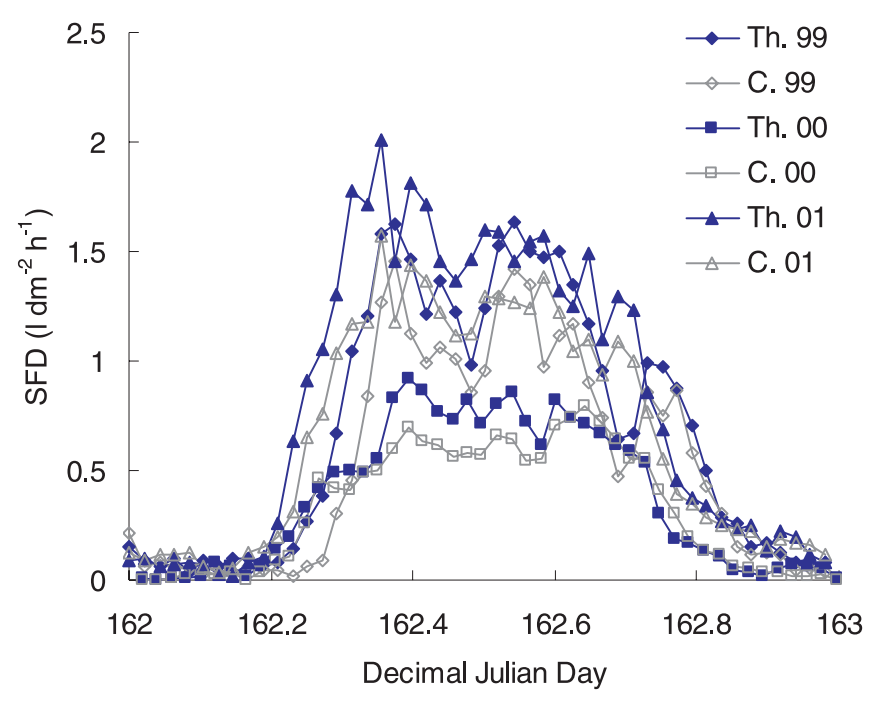

Figure 2. Pedunculate oaks mean sap flux density $\left(S F D, 1 \mathrm{dm}^{-2} \mathrm{~h}^{-1}\right)$ per plot (Th.: thinned; C.: control) for days with comparable PET (2.7 mm), in June (DOY 162 in 1999 and 2000, DOY 163 in 2001). Each curve is the average of all trees $S F D$ for a given plot (see Tab. IV for the number of trees considered). increase in the morning until a maximum value around 8:30 a.m. (UT). For all years, mean $S F D$ is higher in the thinned plot than in the control one. In years 1999 and 2001, mean SFD daily time course present similar curves in shape and amplitude (maximum $S F D$ is $1.5-2 \mathrm{~L} \mathrm{dm}^{-2} \mathrm{~h}^{-1}$ in the thinned plot, $1.5 \mathrm{~L} \mathrm{dm}^{-2} \mathrm{~h}^{-1}$ in the control one) whereas in year 2000 , both plots have mean $S F D$ lower than $1 \mathrm{~L} \mathrm{dm}^{-2} \mathrm{~h}^{-1}$. Mean $S F D$ observed during 1999, 2000 and 2001 seasons (not shown) were, respectively for the thinned and the control plot and from 1999 to $2001,2.5-2-2.75 \mathrm{~L} \mathrm{dm}^{-2} \mathrm{~h}^{-1}$ and $1.7-1.5-2 \mathrm{~L} \mathrm{dm}^{-2} \mathrm{~h}^{-1}$. When comparing $S F D$ between trees with similar $S A$ but from different plot, $S F D$ in the control tree (No. 4 in Tab. II) was $74 \%$ $S F D$ in the thinned one (No. 3 in Tab. II).

Oak SFD daily time course follows closely PET daily time course (Fig. 3), even if the PET curves are smoother. Maple $S F D$ appears to be maximal later (DOY 193 in 2001), i.e. around 11:30-12:00 (UT) and to end up earlier than oak $S F D$, which is probably a consequence of its intermediary position in the canopy [30].

\subsection{Inter-tree Sap Flux Density variability}

Each tree relative contribution to total $S F D$ per period (\% SFD, Tab. IV) and the variation coefficient among trees
DOY 184 (1999) - PET 2.6

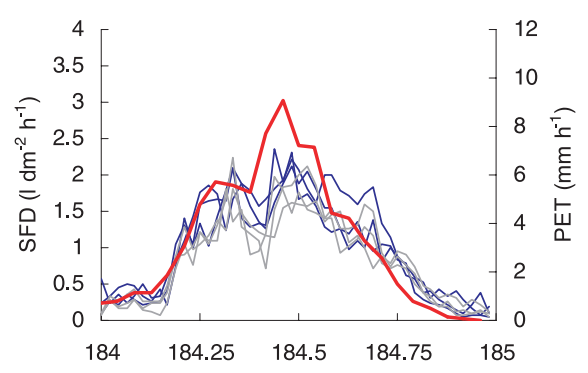

DOY 177 (2000) - PET 2.8

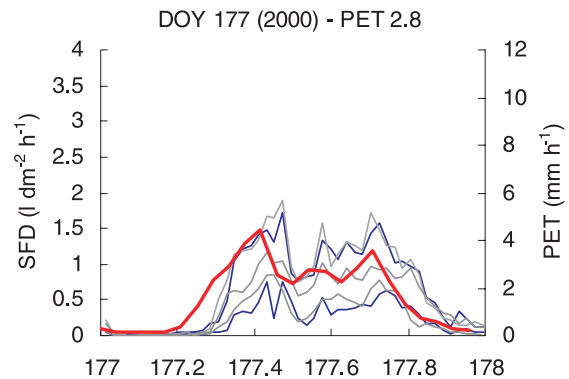

DOY 146 (2001) - PET 2.9

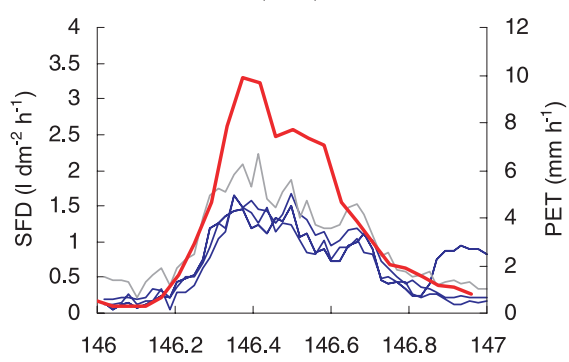

DOY 246 (1999) - PET 2.9

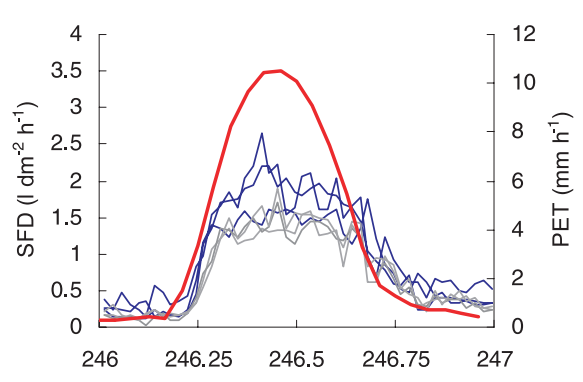

DOY 200 (2000) - PET 3.2

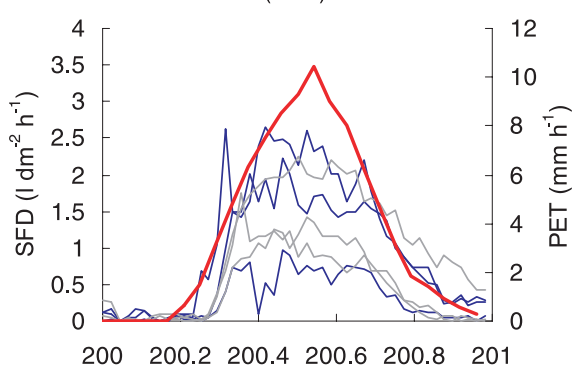

DOY 193 (2001) - P 1.5 mm - PET 2.02

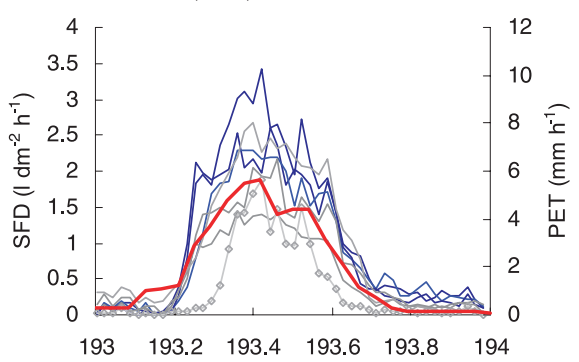

Figure 3. Daily sap flux density ( $S F D$, $1 \mathrm{dm}^{-2} \mathrm{~h}^{-1}$ ) kinetics of the thinned and control trees for two days per year $(D O Y)$. Days are chosen with similar $P E T$. Heavy line: PET; black lines: thinned oaks; grey lines: control oaks; grey line with open symbol: Acer in the control plot. 
Table IV. For each year and each plot (Th.: Thinned; C.: Control), percents of each oak (No.; cf. Tab. II) in the daily total sap flux density $(\% S F D)$ and variation coefficient $(c v \%=$ standard deviation/ arithmetic mean) per period (in julian days). Periods are uniform in terms of measured trees. Periods marked with an * are leaf flushing or caterpillars attack; periods marked with an ${ }^{+}$correspond to leaf fall.

\begin{tabular}{|c|c|c|c|c|c|c|c|}
\hline \multirow{2}{*}{ Year } & \multirow{2}{*}{ Plot } & \multirow{2}{*}{ Period } & \multicolumn{4}{|c|}{$\% S F D$} & \multirow{2}{*}{$c v \%$} \\
\hline & & & No. 1 & No. 2 & No. 3 & No. 4 & \\
\hline \multirow{8}{*}{1999} & \multirow{4}{*}{ Th. } & $150-165^{*}$ & 35 & - & 36 & 29 & 0.20 \\
\hline & & $166-218$ & 35 & - & 32 & 33 & 0.08 \\
\hline & & $219-240$ & 34 & - & 36 & 30 & 0.10 \\
\hline & & $241-303^{+}$ & 32 & - & 38 & 30 & 0.17 \\
\hline & \multirow{4}{*}{ C. } & $150-156^{*}$ & 33.5 & 28.5 & 38 & - & 0.14 \\
\hline & & $157-214$ & 33.5 & 32 & 34 & - & 0.07 \\
\hline & & $215-240$ & 30 & 33 & 37 & - & 0.13 \\
\hline & & $241-303^{+}$ & 28 & 34 & 38.5 & - & 0.21 \\
\hline \multirow{3}{*}{2000} & \multirow{2}{*}{ Th. } & $147-212$ & 39 & - & 22 & 39 & 0.35 \\
\hline & & 213-249 & - & - & 35.5 & 64.5 & 0.41 \\
\hline & C. & $147-249$ & 24 & 33 & 43 & - & 0.37 \\
\hline \multirow{7}{*}{2001} & \multirow{3}{*}{ Th. } & $139-152 *$ & 23 & 20 & 18 & 39 & 0.40 \\
\hline & & $153-167 *$ & 32.6 & 18 & 15 & 34 & 0.42 \\
\hline & & 184-283 & 32 & - & 29 & 39 & 0.23 \\
\hline & \multirow{4}{*}{ C. } & $150-170 *$ & 37 & 63 & - & - & 0.47 \\
\hline & & 184-195 & - & 38 & 35 & 27 & 0.21 \\
\hline & & $221-238$ & 27 & 44 & - & 29 & 0.32 \\
\hline & & $242-283$ & 36 & - & - & 64 & 0.43 \\
\hline
\end{tabular}

$(c v \%)$ gave information on the representativeness of each measured tree: this is important for the up-scaling to stand. In $1999, c v \%$ is always lower than $0.3 \%$, which meant that the respective contribution of each tree to total $S F D$ per day is quite the same. Nevertheless, in both plots, a variation is observed within the trees. For example, in the thinned plot, tree No. 3 and No. 1, which are the ones with the largest $S A$, contribute more to daily $S F D$. In the control plot, excepted for the periods of leaf flushing, the gradient was No. $3>$ No. $2>$ No. 1, which corresponds to a decreasing ranking of $S A$ and crown area (Tab. II). In 2000, the tendency observed in the thinned plot is not confirmed (and $c v \%$ are high), whereas in the control plot, the same ranking is observed between trees. In 2001, the $c v \%$ are high but data are difficult to interpret for several reasons: (i) in the thinned plot, 2 periods out of 3 occur during leaf-flushing and caterpillars attacks, when variability is probably increased and (ii) in the control plot, sap flow measurements dysfunction rendered each period unique and impossible to compare with the others.

\subsection{Tree daily transpiration}

The seasonal time course of daily transpiration followed closely the fluctuations of PET (Fig. 4). In 1999, maximum oak transpiration in the control plot $\left(1 \mathrm{~mm} \mathrm{~d}^{-1}\right)$ was higher than in the thinned plot $\left(0.6 \mathrm{~mm} \mathrm{~d}^{-1}\right)$. In 2000, no differences were observed between plots and stand daily transpiration was around $0.6 \mathrm{~mm} \mathrm{~d}^{-1}$. For technical reasons, the Acer transpiration
Table V. For each year and each plot (Th.: Thinned; C.: Control), oak maximum $L A I(L A I)$, the slope of the $T=f(P E T)$ regression for $P E T \leq 4 \mathrm{~mm} \mathrm{~d}^{-1}(T / P E T)$, and T/LAI $\left(\mathrm{mm} \mathrm{j}^{-1} \mathrm{~m}^{-2}\right)$, with LAI being oak maximum $L A I$.

\begin{tabular}{lcccccccc}
\hline \multirow{2}{*}{ Year } & \multicolumn{3}{c}{ Th. } & & \multicolumn{3}{c}{ C. } \\
\cline { 2 - 3 } \cline { 6 - 8 } & LAI & T/PET & T/LAI & & LAI & T/PET & T/LAI \\
\hline 1999 & 2.8 & 0.21 & 0.16 & & 2.8 & 0.26 & 0.17 \\
2000 & 1.9 & 0.16 & 0.34 & & 2.3 & 0.20 & 0.26 \\
2001 & 2.45 & 0.28 & 0.16 & & 2.45 & 0.22 & 0.21 \\
\hline
\end{tabular}

could only be measured accurately in September and daily transpiration rate reached $0.6 \mathrm{~mm} \mathrm{~d}^{-1}$. In 2001 , frequent flowmeters dysfunction occurred during the monitoring period. The budding of leaves is responsible for the increase of $S F D$ up to 1 $\mathrm{mm} \mathrm{d}^{-1}$ in the control plot and $0.8 \mathrm{~mm} \mathrm{~d}^{-1}$ in the thinned one, between DOY 138 and 146. Right after, SFD decreased, probably as the result of caterpillars attacks, low PET and of the beginning of soil water depletion.

Daily oak transpiration diverged strongly with linearity with increasing PET (Fig. 5), with an inflexion point around $P E T=$ $4 \mathrm{~mm} \mathrm{~d}^{-1}$. The T/PET relationship was therefore characterised linearly for $P E T<4 \mathrm{~mm} \mathrm{~d}^{-1}$ (Tab. V). The slope of the T/PET relationship is always $<0.3$, with a minimum in 2000 (0.16 in the thinned plot and 0.19 in the control one). The importance of $L A I$ as a limiting factor of stand transpiration has been demonstrated [19]. For each year and each plot, T/LAI was calculated for oaks and was always $<0.3$. Except for 2001, T/LAI was larger in the control plot: it varied from 0.19 to 0.27 in the thinned plot and from 0.23 to 0.26 in the control one. In Figure 6, $\Sigma T / \Sigma P E T$ (over a season) is expressed as a function of oak LAI. $\Sigma T / \Sigma P E T$ inter-annual variation with oak $L A I$ is larger in the thinned plot, whereas in the control one, $\Sigma T / \Sigma P E T$ increases with oak $L A I$. Yet, both plots $\Sigma T / \Sigma P E T$ relationships with $L A I$ are consistent with the overall relationship of these parameters, as measured in other forests (Fig. 6b).

\subsection{Herbaceous transpiration and driving variables}

Except for $D O Y$ 131, before oak budburst, the herbaceous transpiration measurement days were characterised by a variable weather, with radiation being mainly diffuse (Tab. VI). Daily time course of transpiration rate $E_{\mathrm{k}}$ (Fig. 7) demonstrated no specific trend. $E_{\mathrm{k}}$ never exceeded $0.14 \mathrm{~mm} \mathrm{~s}^{-1}$ (DOY 131). A correlation was found with below canopy $P A R\left(P A R_{\mathrm{bc}}\right.$; $\left.\mu \mathrm{mol} \mathrm{m} \mathrm{m}^{-2} \mathrm{~s}^{-1}\right)$ :

$$
E_{\mathrm{k}}=0.000068 . P A R_{\mathrm{bc}}+0.04 ; \quad R^{2}=0.61 .
$$

With equation (4), $E_{\mathrm{k}}$ was calculated over the sunny hours at the end of a measurement day. No $E_{\mathrm{k}}$ calculation has been done over the first hours of the days because leaves of the understorey were still wet at that time (dew deposition). By integrating $E_{\mathrm{k}}$ over the entire sunny period, we calculated $E_{\mathrm{d}}\left(\mathrm{mm} \mathrm{d}^{-1}\right.$, Fig. 8). The maximum is observed before tree bud break, with a daily value of $2.9 \mathrm{~mm}$. During the leafy period, forest floor transpiration never exceeded $0.7 \mathrm{~mm} \mathrm{~d}^{-1}$. At the beginning of leaf fall, daily transpiration raised up to $1.8 \mathrm{~mm} \mathrm{~d}^{-1}$. Forest floor $L A I$ (Fig. 8) reached maximal values almost identical to oak $L A I$ 

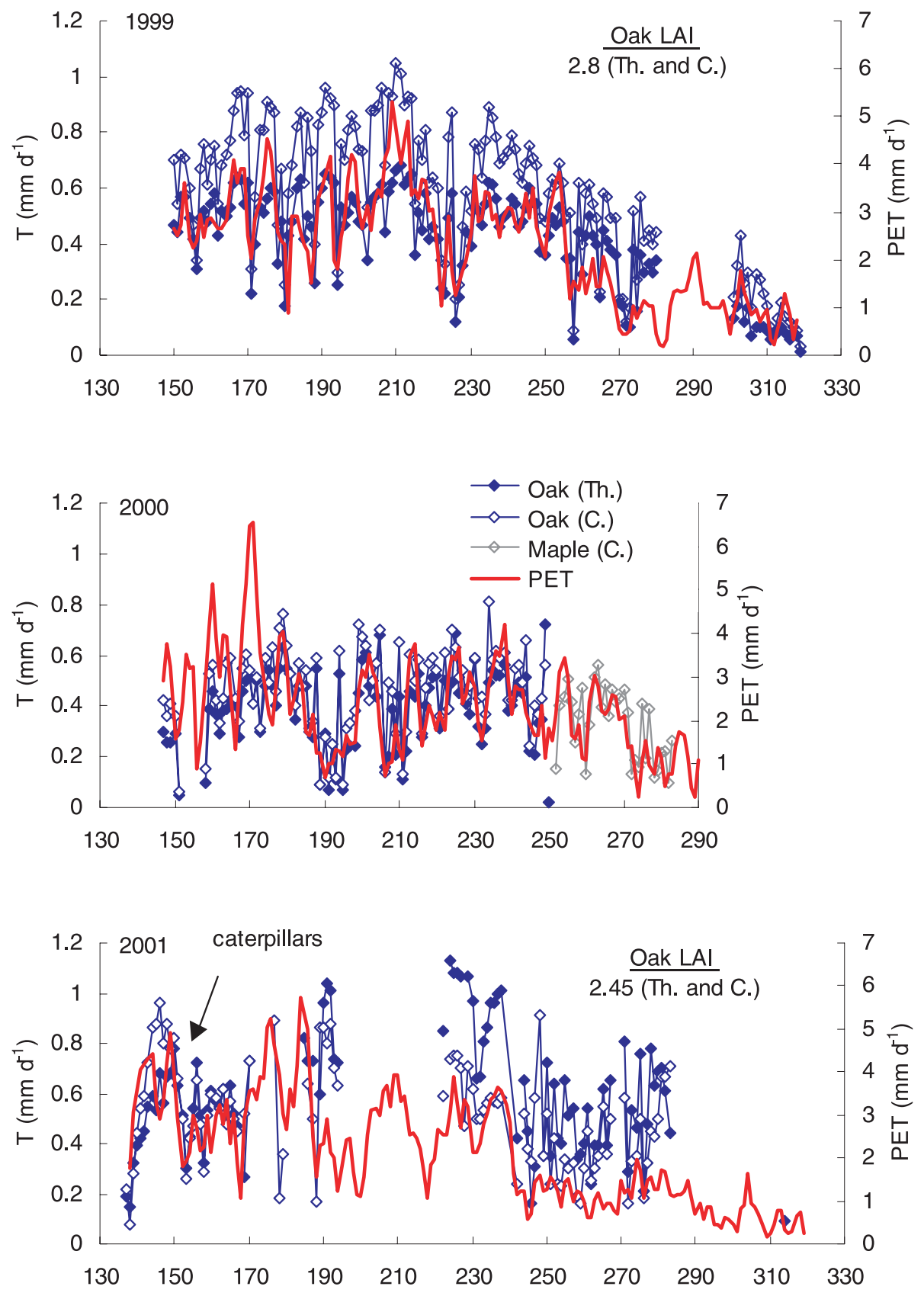

Figure 4. Oak daily transpiration ( $T$, $\mathrm{mm} \mathrm{d}^{-1}$ ) and potential evapotranspiration $\left(P E T, \mathrm{~mm} \mathrm{~d}^{-1}\right)$ in each plot for 1999 , 2000 and 2001 growing season. values, especially in the thinned plot. $E_{\mathrm{d}}$ seasonal evolution was closely related to $L A I$ of the upper layer, as demonstrated by the following equation:

$$
E_{\mathrm{d}}(\mathrm{mm})=-0.9574 . L A I+4.3701 ; \quad R^{2}=0.8215 .
$$

\section{DISCUSSION}

\subsection{Tree $S F D$ and transpiration $(T)$}

In the thinned plot, oak trees $S F D$ are higher than in the control plot, with exceptions for some periods in trees with large $S A$ or crowns. The canopy in the thinned plot is more open, with
$S A$ distributed between fewer trees, with larger and more exposed crowns to light. When integrated to stand scale, the control plot transpired more, as far as oak is concerned, mainly because of that species greater density. The inter-tree variability, estimated through the relative contribution of each tree to total daily $S F D$, confirmed that in thinned and/or declining stands $S F D$ is more heterogeneous $[6,25,26]$. Our results in the thinned plot showed that from year to year, despite its $S A$ or crown area, a tree $S F D$ may be ranking upwards or downwards depending on biological events like caterpillar attacks and their consequences on $L A I$.

Falge et al. [14] and Wullschleger et al. [51] stated that one of the most important aspects that emerge from sap flow 

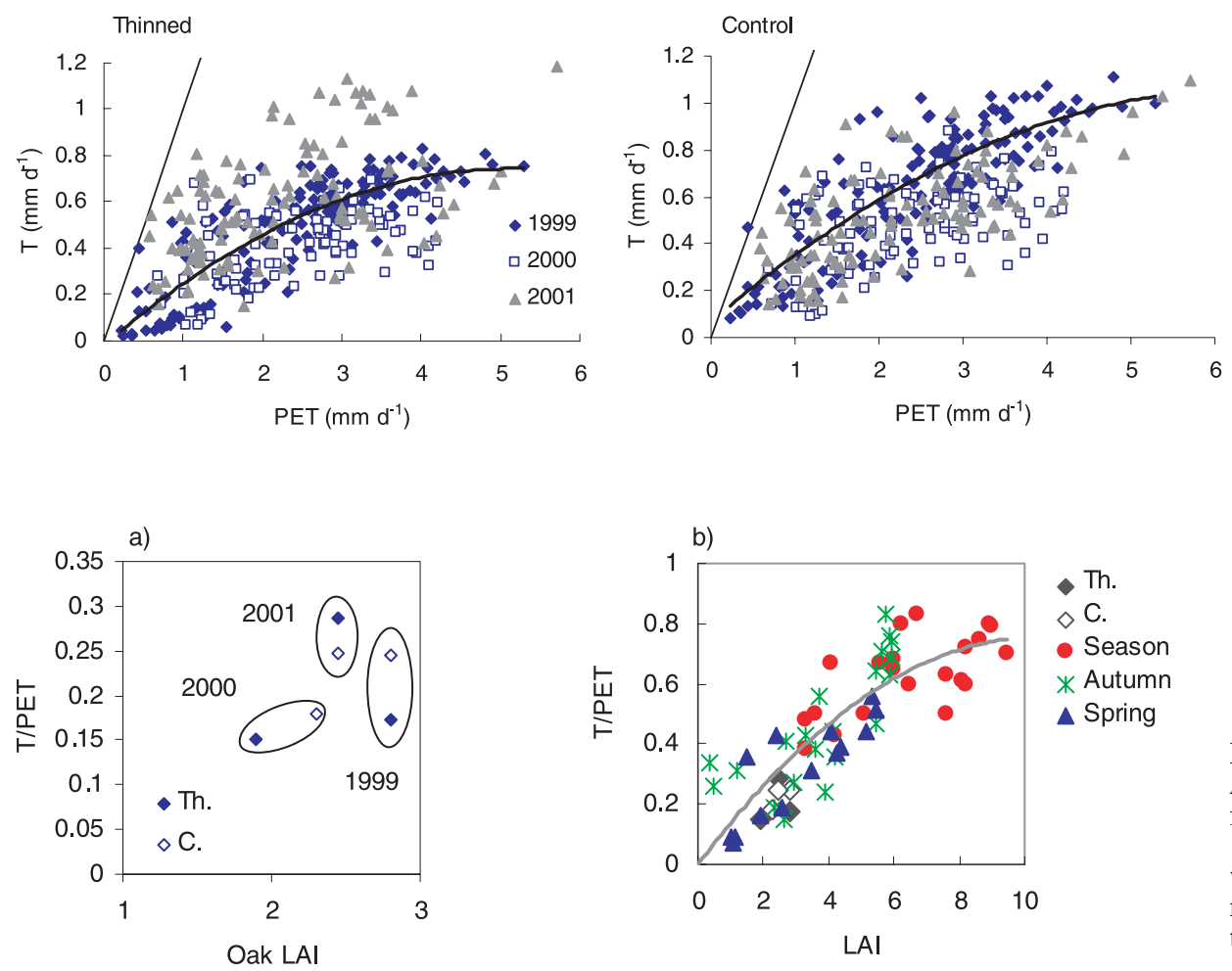

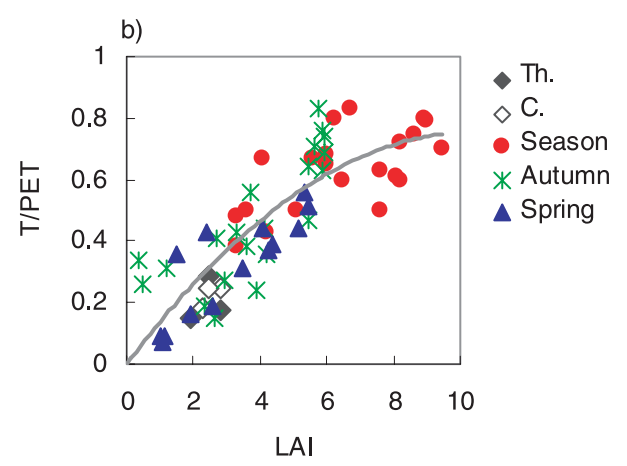

Figure 5. Oak daily transpiration $(T$, $\left.\mathrm{mm} \mathrm{d}^{-1}\right)$ as a function of PET $\left(\mathrm{mm} \mathrm{d}^{-1}\right)$ for 1999,2000 and 2001 growing seasons.
Table VI. Characteristics of the 6 days in 2001 during which forest floor transpiration was measured ; Plot (Th.: thinned; C.: control), day of year $(D O Y)$, incident global radiation $\left(R g_{0}, \mathrm{~J} \mathrm{~cm}^{-2}\right)$, below canopy $P A R\left(P A R_{\mathrm{bc}}, \mu \mathrm{mol} \mathrm{m} \mathrm{m}^{-2} \mathrm{~s}^{-1}\right)$, potential evapotranspiration $\left(P E T, \mathrm{~mm} \mathrm{~d}^{-1}\right), L A I$ (tree total $\left.L A I\right)$, and mean temperature inside the chamber $\left(T^{\circ},{ }^{\circ} \mathrm{C}\right)$.

\begin{tabular}{lcccccc}
\hline Plot & $D O Y$ & $R g_{\mathrm{o}}$ & $P A R_{\mathrm{bc}}$ & $P E T$ & $L A I$ & $T^{\circ}$ \\
\hline Th. & 131 & 1975 & 784 & 4.9 & $(1.1)$ & 27.5 \\
Th. & 173 & 1327 & 263 & 3.9 & 3.05 & 16.9 \\
C. & 213 & 1948 & 49.5 & 2.5 & 4.1 & 20.2 \\
Th. & 223 & 1526 & 208.5 & 2.5 & 3.5 & 17.9 \\
C. & 241 & 1535 & 51.6 & 1.6 & 3.9 & 18.5 \\
Th. & 284 & 731 & 94.2 & 1.1 & 2.5 & 15.2 \\
\hline
\end{tabular}

measurements in trees occupying different places in a canopy, is to estimate how a forest structure or a canopy stratification influences forest water use. Maple SFD daily time course (Fig. 3) demonstrated well that each species position in the canopy architecture has consequences upon its water use. Maple, which is an intermediate species, transpired water on a shorter day period than oak, a dominant species.

The day to day variation of $T$ suggest that oaks are very dynamic in their response to PET. Still, the daily rates of $T$ are very low $\left(0.6\right.$ to $\left.1 \mathrm{~mm} \mathrm{~d}^{-1}\right)$. Other studies cited daily values of $2-3 \mathrm{~mm} \mathrm{~d}^{-1}$ in oak $[6,10]$. In this case, these low values could be attributable to the low $L A I$ or eventually local dryness. Oak $L A I$ is effectively lower than $L A I$ of healthy trees of same age, which are around 5-6 [8]. These low daily rates of $T$ could also be a consequence of xylem water transport impairment via xylem embolism in root and/or stems [34]. Some errors may arise from the sapflow measurement itself, associated with scaling tree estimates [9] or with ring-porous water conducting elements [22]. Some literature focused on sapflow measurement systems comparison $[12,25,50]$, but no generalisation could be made on the reliability of one method among others.

Studies of inter-annual trends in water use of forests offer the opportunity to study a spectrum of biotic and abiotic conditions [37]. The interactions between transpiration, climate, $L A I$, can then be studied [4]. Except in 1999, no differences between oak stand transpiration have been observed between plots: in both plots, the T/PET ratios were very low. Bréda and Granier [4] cited values of 0.4 to 0.89 for an oak stand; Čermák et al. [10], for hundred-years old non declining pedunculate oaks cited T/PET values of 0.8 , as well as Nizinski et al. [35]. This probably results from interacting biological and physical factors: soil constraints (clay content of about 46\%, high bulk density, shrink-swell behaviour [39]), the low oak LAI (caterpillars and decline) can explain those low rates of transpiration, which in turn can explain the low T/PET, PET being relatively very much higher and therefore dampening every transpiration rise. Control trees in this case respond more to PET (and $L A I$ ) than thinned ones, the reason being probably linked with $L A I$ spatial organisation, more heterogeneous in the thinned plot. Plus, an important part of thinned trees $L A I$ is located on epicormic branches.

$T / L A I$ are also low and coupled with $\Sigma T / \Sigma E T P=f(L A I)$, it reinforced the role of $L A I$ as the main limiting factor of transpiration [6, 17, 28]. Körner [24] also pointed out that in temperate deciduous forests, the dominant factor of stand transpiration is $L A I$, with clear transitions between dormancy periods (leaf less) and expanding leaves during growing season. In the 


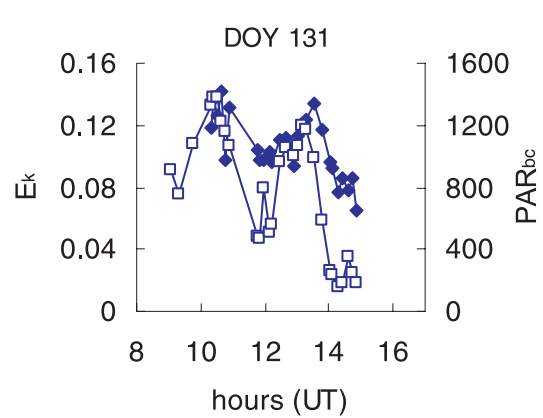

DOY 213
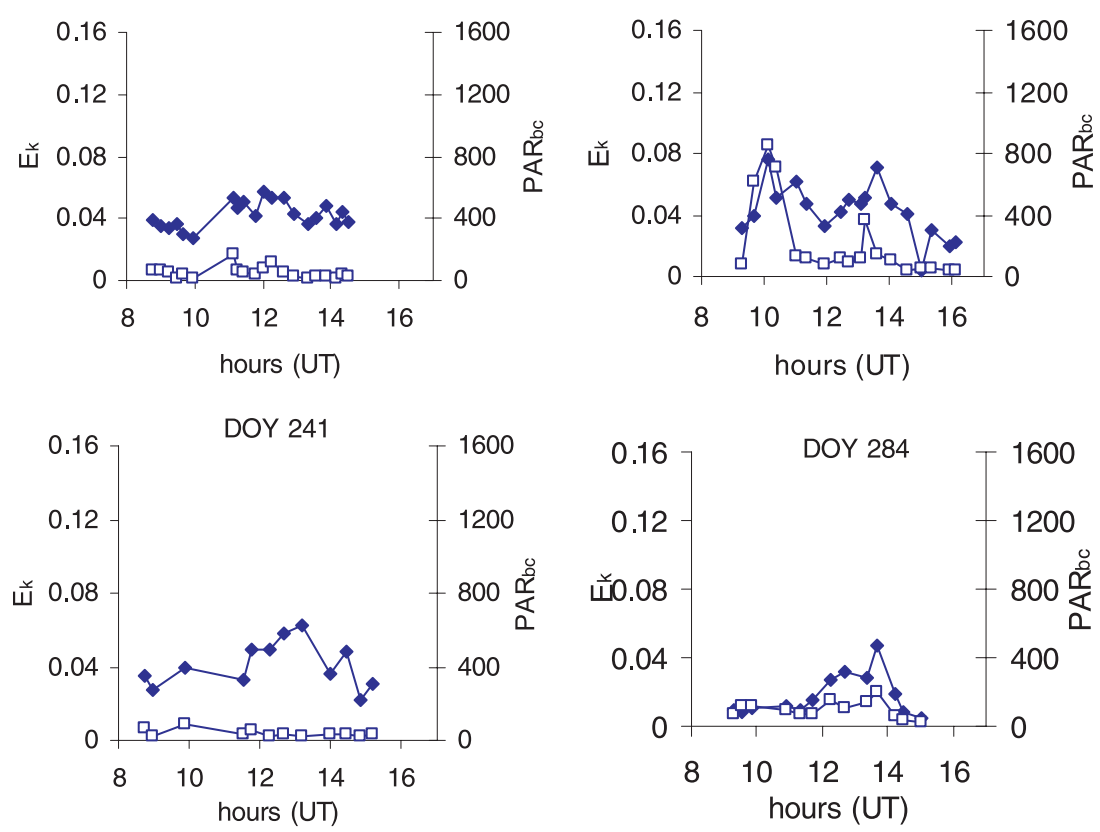

Figure 7. Daily kinetics of forest floor transpiration $\left(E_{\mathrm{k}}, \mathrm{mm} \mathrm{s}^{-1}\right.$; closed symbol) and of $P A R_{\mathrm{bc}}$ $\left(\mu \mathrm{mol} \mathrm{m} \mathrm{m}^{-2} \mathrm{~s}^{-1}\right.$; open symbol). Each point is the value of evapotranspiration fluxes inside the closed chamber on a $2-3$ min period. The hours are expressed in decimal hours $(\mathrm{h}+\mathrm{min} / 60)$, in Universal Time.

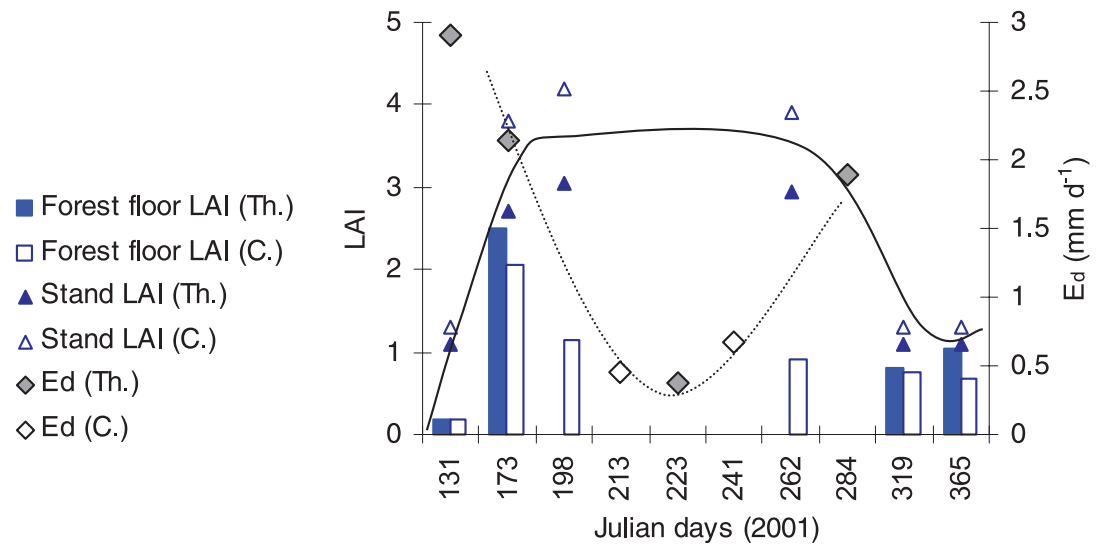

Figure 8. $E_{d}\left(\mathrm{~mm} \mathrm{~d}^{-1}\right)$ as measured with the closed chamber during 6 days in 2001 (lozenges and dotted line). Stand (triangles and heavy line) and herbaceous (histograms) LAI seasonal dynamics are shown as well. thinned plot, the $L A I$ structure inter-annual variability (due in part to caterpillar attacks) could be responsible for the apparent non correlated relationship between T/PET and LAI. The Acer transpiration measurements were managed mainly to estimate the contribution of diffuse porous species in the stand transpiration. Even though they occupy an intermediate position in the canopy architecture, yet they contribute greatly to the stand water use (up to $0.6 \mathrm{~mm} \mathrm{~d}^{-1}$ ).

\subsection{Forest floor evapotranspiration}

In most of forest water use studies, herbaceous transpiration is deduced as the residual term of forest water use minus tree 
water use. Few authors tested the effectiveness of enclosed chamber systems $[13,45]$ which measure directly the water use of a small forest floor surface. In this case, forest floor (evapo-) transpiration appeared to be closely related to $L A I$ and therefore to canopy structure [23, 49] which determines the fraction of the available energy to be delivered to herbs. None of the measurement days was very warm and bright so higher transpiration rates probably occurred during the vegetation period. Still, this layer plays an important role in the forest water use, with maximal values being more than twice oak maximal daily water use. Shrubs transpiration has not been estimated (Prunus spinosa L. in the control plot) but Phillips and Oren [37] showed that their contribution to stand transpiration is $<3 \%$. In terms of water use management, how can an understorey compete with trees? Canopy closure induces a decrease in herbaceous transpiration (as a consequence of $R g_{b c}$ diminution). Nevertheless, this strata stays competitive for water. During dry periods, transpiration reduction concerns more the trees than the herbs [5], those being more "coupled" with the atmosphere. Roberts et al. [40], Loustau and Cochard [27], McNaughton and Jarvis [32] also confirmed the substantial raise of herbaceous transpiration contribution to stand transpiration during dry summer. Still, some uncertainties persist: rooting depth of herbaceous is not known (and therefore its consequences upon water sources), as well as their drought tolerance and their inter-specific differences of transpiratory behaviour.

Acknowledgements: We thank the Forest and Nature Division in Belgium, more particularly the Chimay division, for the stand disposal. We also thank the CDAF laboratory (Chimay) for its helpful assistance for data collection. Thanks also go to F. Hardy, L. Gerlache, G. Rentmeesters, V. Van Hese (UCL) and P. Gross (INRA-Nancy) for technical assistance.

\section{REFERENCES}

[1] Becker M., Lévy G., Le dépérissement du chêne en forêt de Tronçais. Les causes écologiques, Ann. For. Sci. 39 (1982) 439-444.

[2] Becker M., Lévy G., Croissance radiale comparée de chênes adultes (Q. robur L. et $Q$. petraea (Matt.) Liebl.) sur sol hydromorphe acide: effet du drainage, Acta Oecol. Oecol. Plant. 7 (1986) 123143.

[3] Black T.A., Kelliher F.M., Processes controlling understory evapotranspiration, Phil. Trans. Roy. Soc. London B 324 (1989) 207231.

[4] Bréda N., Granier A., Intra- and inter-annual variations of transpiration, leaf area index and radial growth of a sessile oak stand (Quercus petraea), Ann. For. Sci. 53 (1996) 521-536.

[5] Bréda N., Peiffer M., Étude du bilan hydrique des chênaies de la forêt domaniale de la Harth (Haut-Rhin) et impact des épisodes de sécheresse sur la croissance radiale des chênes, Rapport scientifique ONF/INRA, 1998, $60 \mathrm{p}$.

[6] Bréda N., Granier A., Aussenac G., Effects of thinning on soil and tree water relations, transpiration and growth in an oak forest (Quercus petraea (Matt.) Liebl.), Tree Physiol. 15 (1995) 295-306.

[7] Bréda N., Cochard H., Dreyer E., Granier A., Water transfer in a mature oak stand (Quercus petraea): seasonal evolution and effects of a severe drought, Can. J. Forest Res. 23 (1993) 1136-1143.
[8] Čermák J., Práx A., Water balance of a Southern Moravian floodplain forest under natural and modified soil water regimes and its ecological consequences, Ann. For. Sci. 58 (2001) 15-29.

[9] Čermák J., Nadezhdina N., Sapwood as the scaling parameter-defining according to xylem water content or radial pattern of sap flow? Ann. Sci. For. 55 (1998) 509-521.

[10] Čermák J., Ulehla J., Kučera J., Penka M., Sap flow rate and transpiration dynamics in the full-grown oak (Quercus robur L.) in floodplain forest exposed to seasonal floods as related to potential evapotranspiration and tree dimensions, Biol. Plant. 24 (1982) 446460.

[11] Čermák J., Cienciala E., Kučera J., Hallgren J.-E., Radial velocity profiles of water flow in trunks of Norway spruce and oak and response of spruce to severing, Tree Physiol. 10 (1993) 367-380.

[12] Clearwater M.J., Meinzer F.C., Andrade J.L., Goldstein G., Holbrook N.M., Potential errors in measurement of nonuniform sap flow using heat dissipation probes, Tree Physiol. 19 (1999) 681687.

[13] Cochard H., Utilisation d'un système de type "enceinte fermée" pour l'estimation de la transpiration journalière d'un sous-bois de pin maritime (Pinus pinaster Ait.), DEA Écologie végétale, 1988, $37 \mathrm{p}$.

[14] Falge E., Ryel R.J., Alsheimer M., Tenhunen J.D., Effects of stand structure and physiology on forest gas exchange: a simulation study from Norway spruce, Trees 11 (1997) 436-448.

[15] FAO, ISSS Working Group Reference Base. World Reference Base for Soil Resources: Keys to Reference Soil Groups of the World, World Soil resource Report No. 84, FAO, Rome, 1998, 88 p.

[16] Granier A., Une nouvelle méthode pour la mesure du flux de sève brute dans le tronc des arbres, Ann. For. Sci. 42 (1985) 193-200.

[17] Granier A., Évapotranspiration des forêts, C. R. Acad. Agric. Fr. 82 (1996) 119-132.

[18] Granier A., Biron P., Lemoine D., Water balance, transpiration and canopy conductance in two beech stands, Agric. For. Meteorol. 100 (2000) 291-308.

[19] Granier A., Bréda N., Biron P., Villette S., A lumped water balance model to evaluate duration and intensity of drought constraints in forest stands, Ecol. Model. 116 (1999) 269-283.

[20] Granier A., Loustau D., Saugier B., Berbigier P., Bilan hydrique de deux peuplements de pin maritime dans les Landes: évaluation des flux des strates ligneuse et herbacée et de leur variabilité, in: ATP PIREN, Influence à l'échelle régionale des couvertures pédologiques et végétales sur les bilans hydriques et minéraux du sol, Rapport final, 1989, pp. 287-315.

[21] Granier A., Biron P., Bréda N., Pontailler J.Y., Saugier B., Strategies for monitoring and modeling $\mathrm{CO}_{2}$ and water vapor fluxes over terrestrial ecosystems, Thematic issue with selected papers presented at a workshop held at La Thuile, Valle d'Aosta, Italy, 5-9 Mars 1995, Glob. Change Biol. 96 (1996) 265-274.

[22] Granier A., Anfodillo T., Sabatti M., Cochard H., Dreyer E., Tomasi M., Valentini R., Bréda N., Axial and radial water flow in the trunks of oak trees: a quantitative and qualitative analysis, Tree Physiol. 14 (1994) 1383-1396.

[23] Jarvis P.G., McNaughton K.G., Stomatal control of transpiration: scaling up from leaf to region, Adv. Ecol. Res. 15 (1986) 1-49.

[24] Körner C., Leaf diffuse conductance in major vegetation types of the globe, Ecol. Stud. 100 (1994) 463-490.

[25] Köstner B., Granier A., Čermák J., Sapflow measurements in forest stands: methods and uncertainties, Ann. For. Sci. 55 (1998) 13-27.

[26] Köstner B.M.M., Schulze E.D., Kelliher F.M., Hollinger D.Y., Byers J.N., Hunt J.E., Mcseveny T.M., Meserth R., Weir P.L., Transpiration and canopy conductance in a pristine broad-leaved 
forest of Nothofagus - An analysis of xylem sap flow and eddycorrelation measurements, Oecologia 91 (1992) 35-359.

[27] Loustau D., Cochard H., Use of a portable transpiration chamber for estimating evapotranspiration in the Molinia caerulea understorey of a maritime pine stand, Ann. Sci. For. 48 (1991) 29-45.

[28] Lüttschwager D., Rust S., Wulf M., Forkert J., Hüttl R.F., Tree canopy and herb layer transpiration in three Scots pine stands with different stand structures, Ann. For. Sci. 56 (1999) 265-274.

[29] Malaisse F., Burgeon D., Degreef J., Deom B., Van Doren B., Le dépérissement des chênes indigènes en Europe occidentale, Note 1 : symptômes de perte de vitalité - Fiche technique $n^{\circ} 2$, Belg. J. Bot. 126 (1993) 191-205.

[30] Martin T.A., Brown K.J., Čermák J., Ceulemans R., Kučera J., Meinzer F.C., Rombold J.S., Sprugel D.G., Hinckley T.M., Crown conductance and tree and stand transpiration in a second-growth Abies amabilis forest, Can. J. For. Res. 27 (1997) 797-808.

[31] Mathieu F., Étude de la transpiration des couverts d'érable à sucre et de sapins baumiers à partir de mesures de flux de sève et de mesures micrométéorologiques : de l'arbre au peuplement, DEA en Fonctionnement physique, chimique et biologique de la biosphère continentale, INA-PG, Paris VI, ENS, 1999, 55 p.

[32] McNaughton K.G., Jarvis P.G., Predicting effects of vegetation changes on transpiration and evaporation, in: Kozlowski T.T. (Ed.) Water deficits and plant growth, VII, NY, Academic Press, 1983, pp. $1-47$.

[33] Nageleisen L.-M., Les dépérissements d'essences feuillues en France, Rev. For. Fr. 45 (1993) 605-620.

[34] Nardini A., Salleo S., Trifilo P., Lo Gullo M.A., Water relations and hydraulic characteristics of three wood species co-occurring in the same habitat, Ann. For. Sci. 60 (2003) 297-305.

[35] Nizinski J., Morand D., Saugier B., Variation of stomatal resistance with leaf age in Quercus petraea: effect on the soil-water balance of an oak forest, Ann. For. Sci. (1989) 429-432.

[36] Penman H.L., Natural evaporation from open water, bare soils, and grass, Proc. R. Soc. Ser. A. 193 (1948) 120-145.

[37] Phillips N., Oren R., Intra- and inter-annual variation in transpiration of a pine forest, Ecol. Appl. 11 (2001) 385-396.

[38] Phillips N., Oren R., Zimmermann R., Radial patterns of xylem sapflow in non-, diffuse- and ring-porous tree species, Plant Cell Environ. 19 (1996) 983-990.
[39] Rémy J., Carte des sols de la Belgique: planchette de Seloignes $190 \mathrm{E}$, Centre de cartographie des sols de Belgique méridionale, 1980, Gembloux.

[40] Roberts J., Pymar C.F., Wallace J.S., Pitman R.M., Seasonal changes in leaf area, stomatal conductance and transpiration from bracken below a forest canopy, J. Appl. Ecol. 17 (1980) 409-422.

[41] Smith D.M., Allen S.J., Measurements of sap flow in plant stems, J. Exp. Bot. 47 (1996) 1833-1844.

[42] Swanson R.H., Significant historical developments in thermal methods for measuring sap flow in trees, Agric. For. Meteorol. 72 (1994) 113-132.

[43] Thierron V., Gloesener Y., André P., Rapport final du projet “mise au point et application de traitements de restauration", UCL, Unité des Eaux et Forêts, 1995, 75 p.

[44] Thomas F.M., Hartmann G., Soil and tree water relations in mature oak stands of northern Germany differing in the degree of decline, Ann. For. Sci. 53 (1996) 697-720.

[45] Vaugeois Y., Étude des échanges de $\mathrm{CO}_{2}$ au niveau d'un sous-bois de pin maritime, INRA, Laboratoire d'écophysiologie CestasGironde, 1994, 27 p.

[46] Vincke C., Approche écophysiologique des flux d'eau au sein d'une chênaie pédonculée $(Q$. robur $\mathrm{L}$.) dépérissante sur sol à régime hydrique alternatif, Thèse, UCL, 2003, 392 p.

[47] Vincke C., Delvaux B., Porosity and avalilable water of temporarily waterlogged soils in a Quercus robur (L.) declining stand, Plant Soil 274 (2005) 189-203.

[48] Vincke C., Granier A., Bréda N., Devillez F., Evapotranspiration of declining Quercus robur (L.) stand from 1999 to 2001. II. Daily actual evapotranspiration and soil water reserve, Ann. For. Sci. (2005) (in press).

[49] Wedler M., Heindl B., Hahn S., Köstner B., Bernhofer C., Tenhunen J.D., Model-based estimates of water loss from "patches" of the understory mosaic of the Hartheim Scots pine plantation, Theor. Appl. Climatol. 53 (1996) 135-144.

[50] Wullschleger S.T., Meinzer F.C., Vertessy R.A., A review of whole-plant water use studies in trees, Tree Physiol. 18 (1998) 499512.

[51] Wullschleger S.D., Wilson K.B., Hanson P.J., Environmental control of whole-plant transpiration, canopy conductance and estimates of the decoupling coefficient for large red maple trees, Agric. For. Meteorol. 104 (2000) 157-168. 